\title{
Marginal marine agglutinated foraminifera: affinities for mineral phases
}

\author{
KATHRYN ALLEN, STEPHEN ROBERTS \& JOHN W. MURRAY \\ School of Ocean and Earth Science, Southampton Oceanography Centre, University of Southampton, European Way, Southampton SO14 3ZH, \\ UK.
}

\begin{abstract}
The major agglutinated constituents in test material of marginal marine foraminifera are identified as $\alpha$-quartz and clay particles using complementary spectroscopic techniques. Electron dispersive scattering analysis, micro-laser Raman and Fourier transform infrared (FTIR) spectroscopic techniques revealed detail about elemental and mineral polymorph constituents in test walls. Additionally, FTIR identifies the existence of organic cements and lining materials in wall structures. Micro-laser Raman specifically characterized the titanium oxide mineral, anatase, as a distinctive fraction of agglutinate in Ammobaculites balkwilli Haynes. The mineral represents $\approx 10 \%$ of the test material, but comprises a minor component of the sediment and is identified in sediments only after heavy mineral separation. The enhanced concentration of anatase in the test of $A$. balkwilli suggests that there is a preferential selection for anatase. This provides further evidence that certain foraminifera can select grains specifically, which implies that there exists a selective mechanism and interaction between the organic (secreted) phases in the test walls and inorganic (grain surface) materials. J. Micropalaeontol. 18(2): 183191, December 1999.
\end{abstract}

\section{INTRODUCTION}

Few biochemical and mineral microprobe investigations have been completed on agglutinated foraminifera, although previous microprobe studies have successfully revealed information about the mineral content and the nature of mineral polymorphs present in test walls (Towe, 1977; Lefurgey, 1978; Vénec-Peyré \& Jaeschke-Boyer 1978, 1979; Weiner \& Erez, 1985; Gooday et al., 1994; Roberts \& Murray, 1995). Accounts of test morphotypes and features in agglutinated foraminifera prior to the introduction of electron dispersive scattering (EDS) analysis, micro-laser Raman and Fourier transform infrared (FTIR) microprobes, were unable to provide precise information about the components in wall structures. The development of more sophisticated analytical techniques provides high spatial resolution to $\approx 2 \mu \mathrm{m}$, allowing the identification of the precise inorganic polymorphs used and secreted by foraminifera in test construction (Roberts \& Murray, 1995). These data are of crucial importance as the microstructural nature of wall structures - for example, the cement morphology - continues to be one of the most important classification characteristics (Bender \& Hemleben, 1988; Hohenegger, 1990). The acquisition of more precise geochemical data further enhances the information already available.

A combination of the above techniques was used to analyse the nature and composition of test components of Ammobaculites balkwilli Haynes, Trochammina inflata (Montagu), Jadammina macrescens (Brady) and Miliammina fusca (Brady), agglutinated foraminifera from marginal marine areas near Southampton, UK. The three spectroscopic techniques applied vary in the way that they interact with sample surfaces, enabling the acquisition of a variety of data (Fig. 1). These analytical techniques allowed the identification of the nature of inorganic and organic components in the test walls of foraminifera. Such data may reveal whether the foraminifera are specifically selecting material from their immediate environment. A detailed description of the organic component analysis is given in Allen et al. (in press). This paper characterizes material in the agglutinated walls and discusses evidence for specific particle selection on the basis of mineralogy by foraminifera.

\section{ANALYTICAL PROCEDURES}

Surface sediment samples were collected from marginal marine environments (marsh and intertidal mudflats) at Swanwick and Warsash near Southampton, washed on a $63 \mu \mathrm{m}$ sieve, and dried at $50^{\circ} \mathrm{C}$.

For scanning electron microscopy (SEM), the specimens were mounted onto aluminium stubs and coated with carbon before introduction into the vacuum chamber of the Jeol JSM-6400 scanning electron microscope with a Tracor Series II energy dispersive X-ray analysis system. Photographs were taken so that a point correlation with EDS analysis could be made. Semiquantitative point analysis was performed on individual grains and the results collected.

Raman spectroscopy was carried out with a Jobin-Yvon S3000 microprobe using an Olympus BH-2 microscope fitted with a Nikon $\times 80$ objective. The $514 \mathrm{~nm}$ line of an $\mathrm{Ar}$ ion laser (coherent Innova Model 70) was used with a source power of $2-4 \mathrm{~mW}$. Selected specimens were placed loose on a glass slide and analysed using the Raman laser microprobe in the $100-1000 \mathrm{~cm}^{-1}$ region of the spectrum. In this study, integration times of $10-300 \mathrm{~s}$ with a single accumulation were used with each analysis taking about $6 \mathrm{~min}$ to complete. Calibration was achieved through monitoring plasma lines from the laser and through the use of quartz and sulphur standards. The spectra were processed and manipulated with ISA PRISM software. The peak position was determined at maximum intensity and the line-width measured at half-maximum intensity (Roberts et al., 1995).

Fourier transform infrared analysis was performed with a Nicolet 460 Protégé, magna IR technology FTIR microprobe with a Nic-plan IR microscope. The data were acquired and manipulated with Omnic software. The IR bench conditions were as follows throughout the analysis: acquisition time $200 \mathrm{~s}$, band resolution $4 \mathrm{~cm}^{-1}$ and gain 2-4. Background subtraction 


\section{Scanning Electron Microscopy}

\section{Laser Raman Microprobe}

\section{FT Infrared}

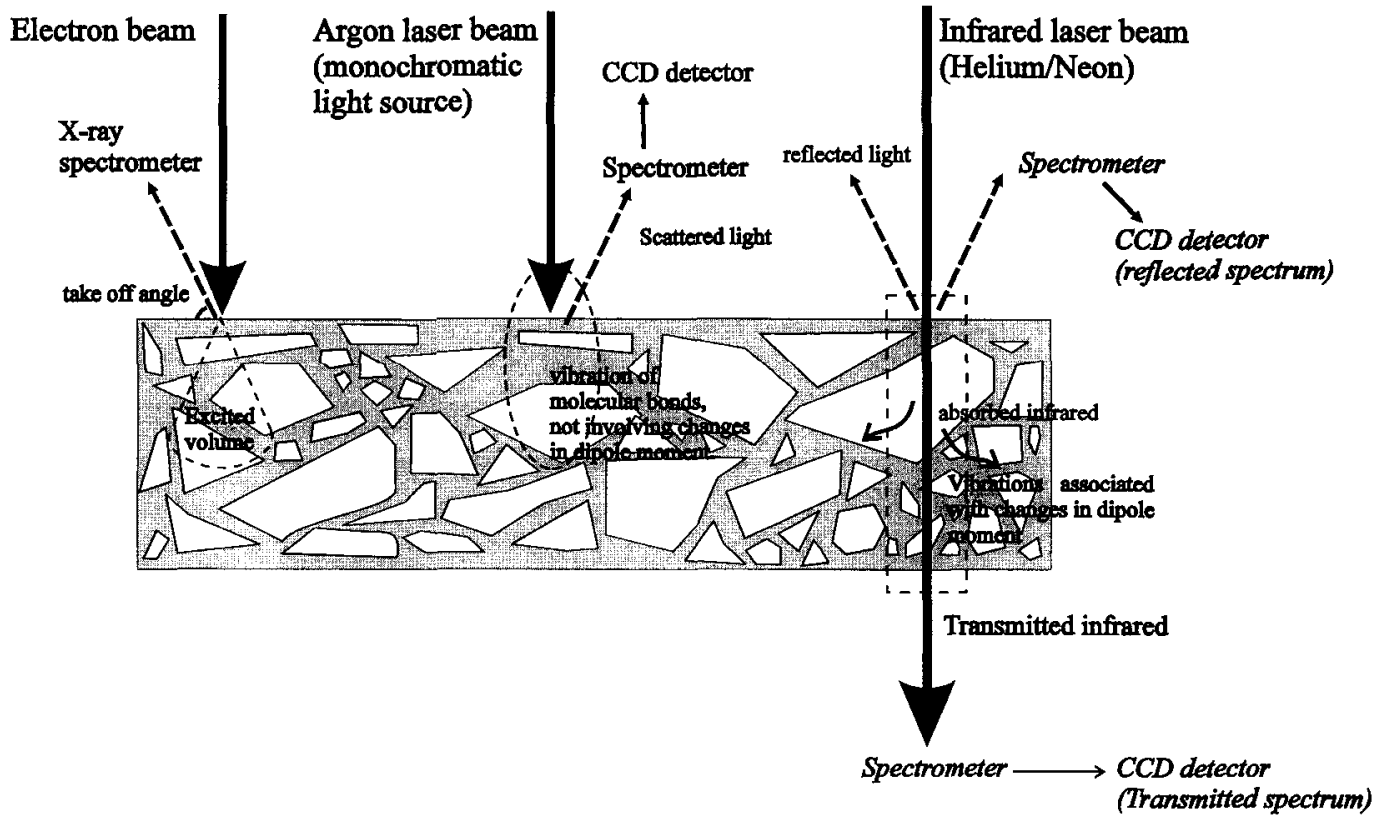

Fig. 1. Simplified annotated diagram of the techniques used in the analysis of the foraminifera shells: scanning electron microscopy, Fourier transform infrared (FTIR) and Raman spectroscopy. Electron Dispersive scattering (EDS) analysis involves X-ray excitation of the sample surface and the area in a teardrop shape below; an accelerating voltage of $20-30 \mathrm{kV}$ for EDS will analyse an area approximately $3-4 \mu \mathrm{m}$ on the surface of a specimen. In the Raman technique a monochromatic beam of light is directed onto a medium (foraminiferal test) and the scattered light is analysed for shifts in frequency above and below that of the original incident frequency. Vibrations of molecular bonds, not involving any change in dipole moment, cause the Raman effect. The laser Raman microprobe can sample areas down to approximately $2 \mu \mathrm{m}$ spot sizes. FTIR is transmitted through the sample, whereupon certain bonds, which are infrared active, absorb energy. For a vibrating mode to be infrared active it must be associated with a changing dipole moment. Infrared light is reflected, absorbed and transmitted through the sample. In FTIR analysis a spot size from 25 to $100 \mu \mathrm{lm}$ is used for analysis. CCD, charge coupled device.

took place after each acquisition to remove additional components from the spectra. The spectral range was $4000-600 \mathrm{~cm}^{-1}$. Noise levels were monitored throughout the experiments and were found to be very low. Sections of foraminifera test were placed on a salt window for analysis by FTIR.

X-Ray diffraction (Philips) analyses were performed on sediments collected from the same area as the foraminifera. A 1.00 mass of bulk sediment was ground and the resultant powder was scanned from 2 to $70^{\circ} 2 \theta$ at a scanning velocity of $1.2^{\circ} / \mathrm{min}$ using Ni-filtered $\mathrm{CoK} \alpha$ radiation. Peaks were identified using the associated computer software. Additionally, heavy minerals and clays were separated from the sediment fraction and analysed under the same conditions.

\section{RESULTS}

Test coloration of selected agglutinated foraminifera was initially examined using a binocular microscope. Jadammina macrescens and $T$. inflata have tests which are light grey to brown in colour. Younger chambers can often be seen to be lighter in coloration compared with the rest of the test. Miliammina fusca has a white to brown test which appears to be finely agglutinated and $A$. balkwilli has a test which consists of angular, medium to coarse, white and dark grains.

\section{Scanning electron microscopy}

Scanning electron microscopy of the foraminifera indicates that all the specimens selected have detrital grains as the main constituent of the wall structure. A fibrous cement phase, holding the grains together, is observed at high magnifications. Jadammina macrescens, $T$. inflata and $M$. fusca have abundant cement interstitial to the detrital grains, whereas $A$. balkwilli has coarser grains with a lower proportion of cement (Plate 1). $T$. inflata and $J$. macrescens have very similar wall morphology, with outer and inner linings surrounding the test wall. Detrital grains are fairly angular, occasionally tabular. The latter are commonly orientated with the long axis parallel to the test linings and often produce grain imprints in the outer lining (Plate 1, figs 1, 2, 5,6). M. fusca has abundant medium clay/siltsized grains, with additional epipelic diatom frustules. The test has no clear outer lining, rather a dense layer of organic material coating the grains on the outer surfaces (Plate 1, figs 3, 7). Detrital grains in the test walls of $T$. inflata, J. macrescens and $M$. fusca are approximately $<1-4 \mu \mathrm{m}$ in size and are representative of the clay- to silt-sized portion of the sediment, whereas specimens of $A$. balkwilli have coarser grains in the size range $10-50 \mu \mathrm{m}$, which are representative of the silt-sand-sized portion of the sediment (Plate 1, figs 4, 8). 

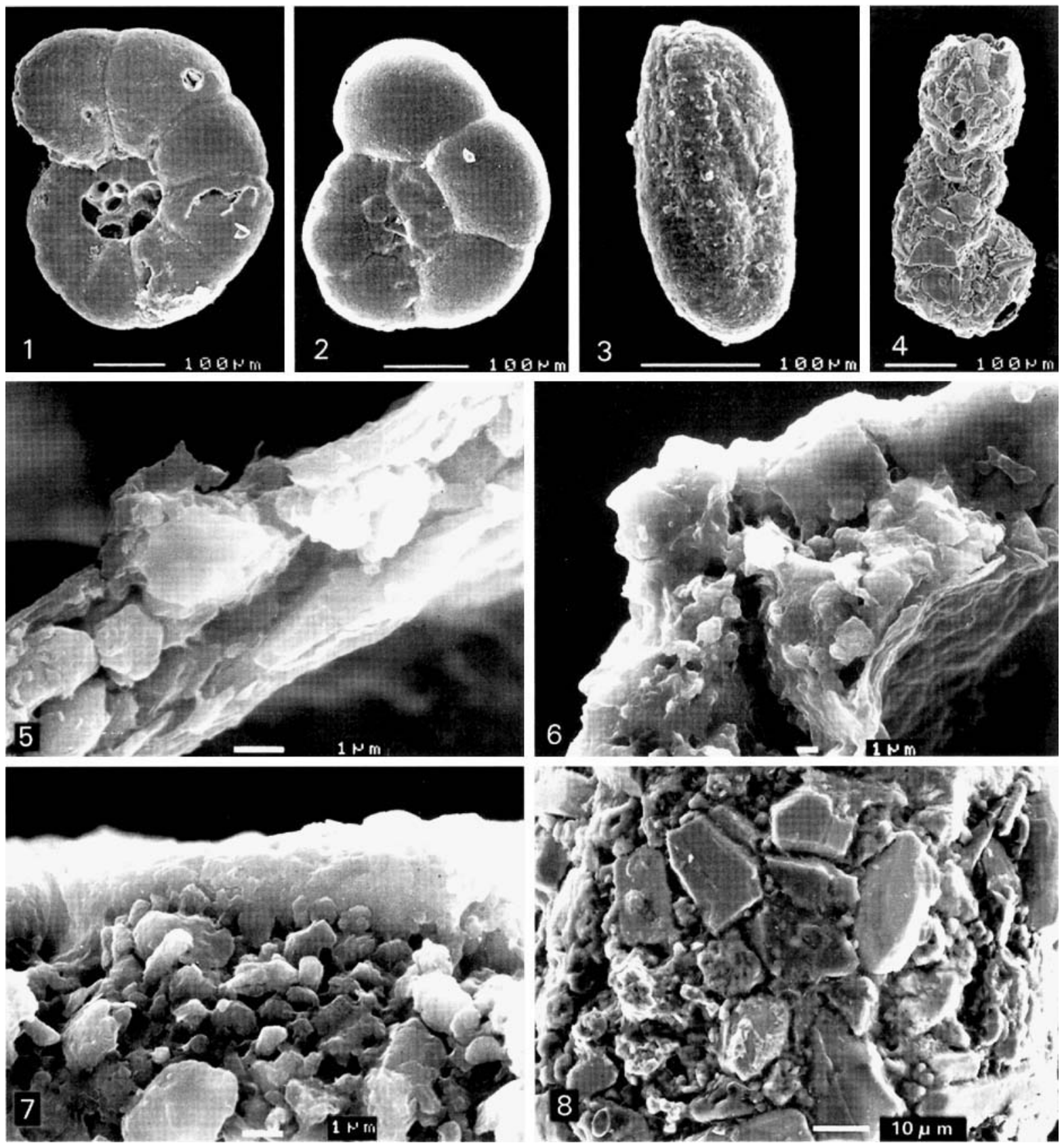

Explanation of Plate 1.

Scanning electron photo micrographs of the four marginal marine foraminifera investigated by the microprobe techniques. Test morphology and wall sections of Jadammina macrescens (figs 1, 5), Trochammina inflata (figs 2, 6), Miliammina fusca (figs 3, 7) and Ammobaculites balkwilli (figs 4, 8).

The elemental compositions of the test walls were acquired through EDS analysis. T. inflata, J. macrescens and $M$. fusca show spectra indicating that quartz is the main detrital grain held in the test (Fig. 2A). In the spectral analysis, the additional presence of $\mathrm{Al}$, along with lower proportions of $\mathrm{Mg}$ and $\mathrm{Na}$, suggests that feldspars and clays may also be present as the levels of $\mathrm{Mg}, \mathrm{Na}$ and $\mathrm{Al}$ are in excess of that reported from quartz analysis (Deer et al., 1966) (Fig. 2B). A. balkwilli shows similar spectra, indicating the presence of quartz with minor aluminosilicates, i.e. clays and feldspar particles. Certain spectra of $A$. balkwilli indicate that $\mathrm{Ti}$ oxides, possibly anatase and rutile, are present in the test (Fig. 2C).

\section{Raman spectroscopy}

Results from the Raman laser microprobe analysis are outlined in Fig. 3. As a result of the presence of a brown layer on the outside of the tests (thought to be an Fe-rich coating), the specimens were initially difficult to analyse due to the high 

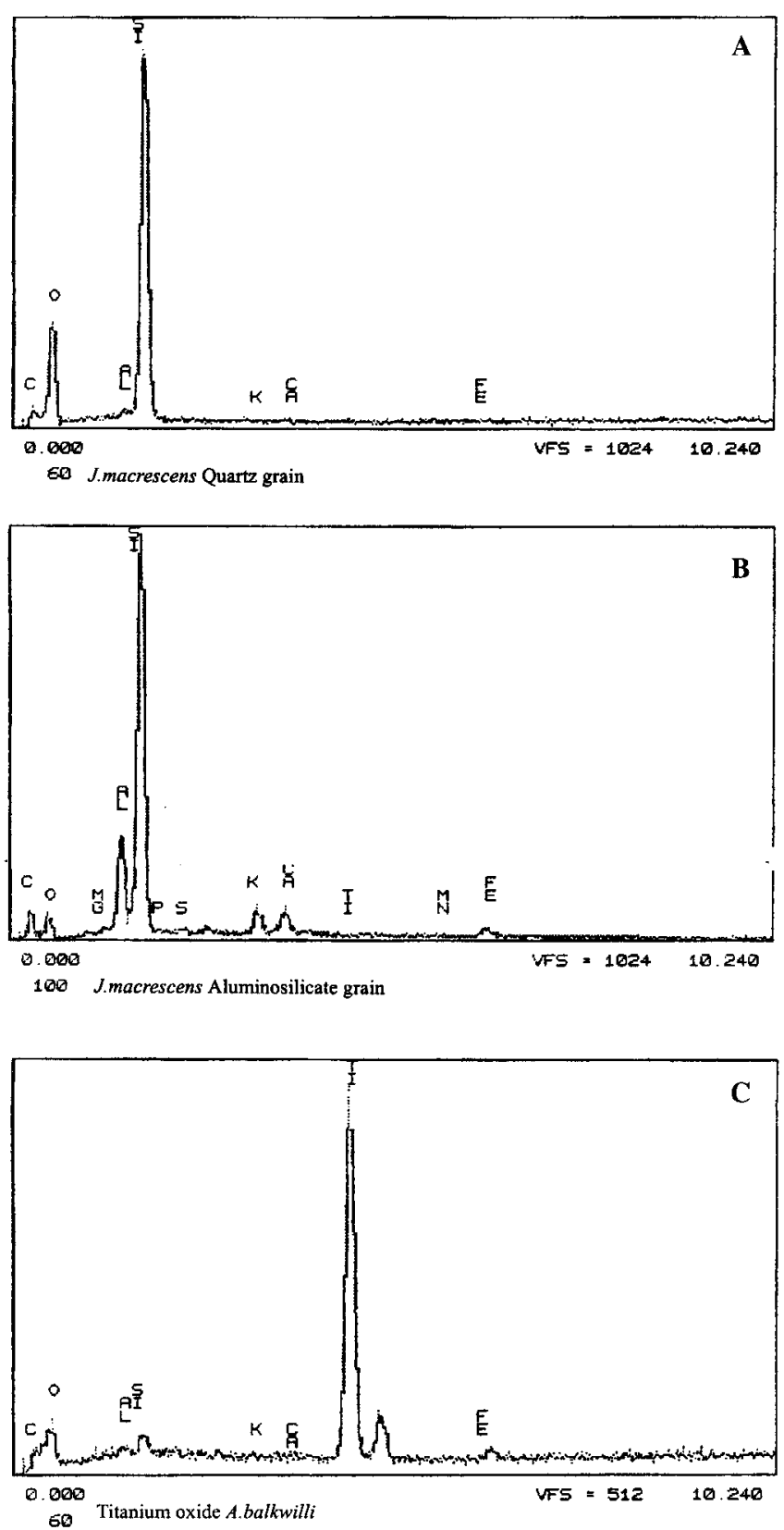

Fig. 2. Spectra obtained from electron dispersive scattering analysis on agglutinated foraminifera shells. Spectrum $\mathbf{A}$ is representative of the analysis of quartz grains $\left(\mathrm{SiO}_{2}\right)$ from test agglutinate. Spectrum B represents a mixed elemental composition arising from aluminosilicate mineral phases. Dark grains held within the test of A. balkwilli, represented by spectrum $\mathbf{C}$, have $\mathrm{TiO}_{2}$ compositions, indicative of the presence of rutile or anatase.

levels of fluorescence. Short acquisition times were used $(120 \mathrm{~s})$, with the spectra showing intense bands in the lower wavenumber region. J. macrescens, $M$. fusca and $A$. balkwilli show spectra confirming $\alpha$-quartz as the main constituent of their agglutinated material with characteristic bands at 128, 393 and $464 \mathrm{~cm}^{-1}$.

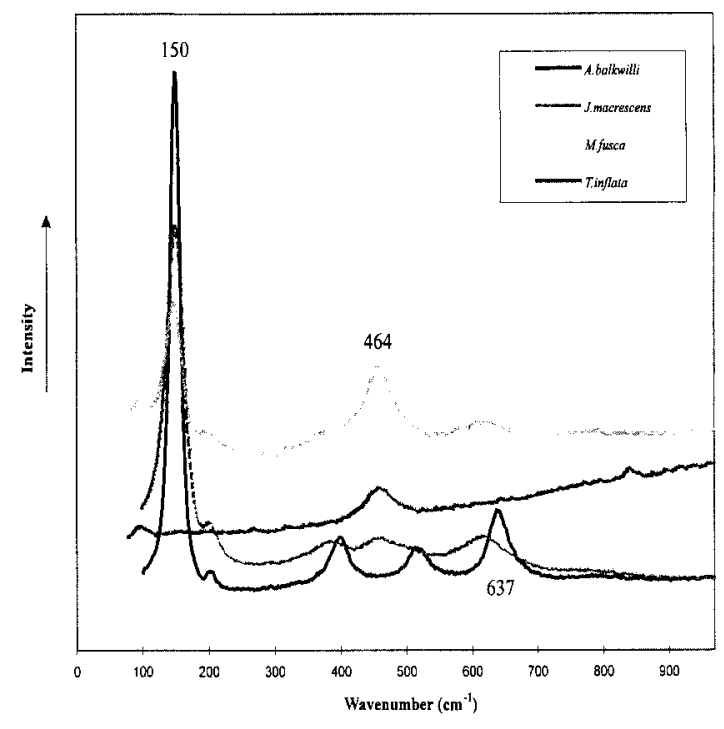

Fig. 3. Combined Raman spectra $\left(100-1000 \mathrm{~cm}^{-1}\right)$ obtained from analysis of all agglutinated foraminifera shells. The intensity of the $150 \mathrm{~cm}^{-1}$ peak in $J$. macrescens, $M$. fusca, is significant and occurs in spectra obtained from clay minerals due to the vibration of the $\mathrm{AlO}_{6}$ groups in kaolinite. The $A$. balkwilli spectrum also has a strong absorption at $150 \mathrm{~cm}^{-1}$ arising from the bending of $\mathrm{O}-\mathrm{Ti}-\mathrm{O}$ structures, and others at $197,400,515$ and $640 \mathrm{~cm}^{-11}$, representative bands from the analysis of anatase (Frost, 1997). Bands at 128,379 and $464 \mathrm{~cm}^{1}$ visible in spectra are representative of quartz.

An intense band at $\approx 150 \mathrm{~cm}^{-1}$ is observed in certain Raman spectra from $J$. macrescens and $M$. fusca which is in addition to the bands consistent with $\alpha$-quartz. Kaolinite spectra typically show bands at $150,461,512$ and $637 \mathrm{~cm}^{-1}$ (Johnston et al., 1985). The $150 \mathrm{~cm}^{-1}$ band is characteristic for the symmetrical bend of the $\mathrm{AlO}_{6}$ group in kaolinite (Frost, 1997), indicating that this clay mineral is a constituent of agglutinated material, correlating with the EDS spectral results with mixed aluminosilicate composition (Frost, 1997; Johnston et al., 1985). Certain T. inflata spectra also have medium-intense absorption at $\approx 150 \mathrm{~cm}^{-1}$, with additional vibrational bands at $175,219,289$ and $488 \mathrm{~cm}^{-1}$, although other spectra possess absorptions at 92 , 456 and $841 \mathrm{~cm}^{-1}$. The spectra are difficult to characterize as the signal appears to be highly mixed, despite a collection spot size average of $\approx 2 \mu \mathrm{m}$. The spectral bands identified in $T$. inflata spectra are not directly correlatable with published pure mineral values, indicating that a mixed suite of minerals may be present in the agglutinate. Certain bands are comparable with those in montmorillonite $(450 / 467,521,621,843$; Johnston et al., 1985) and mica $\left(100,160,195,220,240 \mathrm{~cm}^{-1}\right.$; Loh, 1973), indicating the potential presence of these minerals.

Ammobaculites balkwilli spectra are different as an intense absorption at $\approx 150 \mathrm{~cm}^{-1}$ occurs with others at $128,201,397$, 464,518 and $637 \mathrm{~cm}^{-1}$. Bands at 128,397 and $464 \mathrm{~cm}^{-1}$ suggest that $\alpha$-quartz and kaolinite are present as detrital material (128 and $464 \mathrm{~cm}^{-1}$ ), agreeing with EDS analysis determining grains with mixed aluminosilicate composition. Analysis of darker grains with laser Raman acquired spectra with an intense peak at c. $150 \mathrm{~cm}^{-1}$, attributed to the $\mathrm{O}-\mathrm{Ti}-\mathrm{O}$ symmetrical bend (Frost, 1997), with additional low intensity bands at 197, 400, 


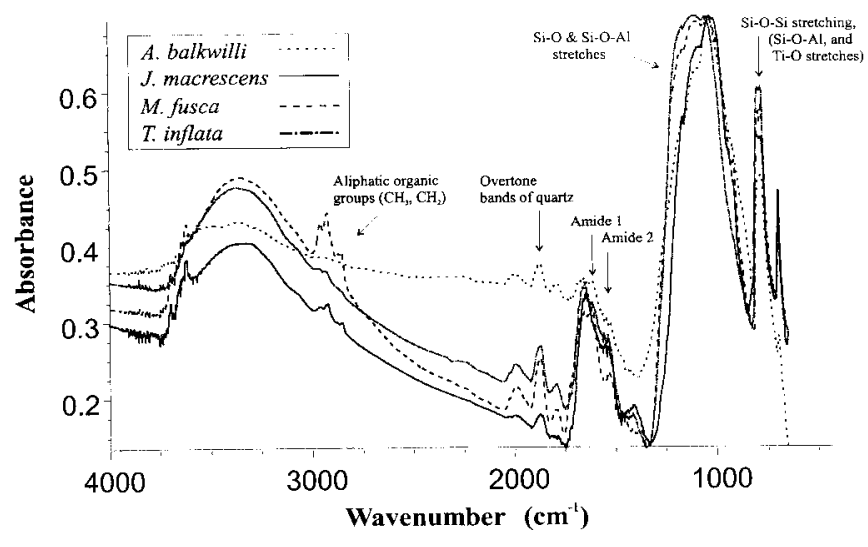

Fig. 4. Combined Fourier transform infrared spectra $\left(400-4000 \mathrm{~cm}^{-1}\right)$ obtained from the analysis of all agglutinated foraminifera shells. Significant bands are evident in the regions around $\approx 700 \mathrm{~cm}^{1}(\mathrm{Si}-\mathrm{O}-\mathrm{Si}$, $\mathrm{Si}-\mathrm{O}-\mathrm{Al}$ and $\mathrm{Ti}-\mathrm{O}$ molecular vibrations) and $800-1000 \mathrm{~cm}^{-1}$, representative of silicate and aluminosilicate minerals with $\mathrm{Si}-\mathrm{O}$ and $\mathrm{Si}-\mathrm{O}-\mathrm{Al}$ stretches. Overtone absorptions from quartz (Shimoda \& Aikawa 1994) are identified at 1796,1883 and $1991 \mathrm{~cm}^{1}$. Absorptions in the regions $1500-1600$ and $2800-3000 \mathrm{~cm}^{-1}$ arise from the vibration of organic materials in the test wall. The broad absorption between 3000 and $3800 \mathrm{~cm}^{-1}$ is produced from fundamental $\mathrm{OH}$-stretching vibrations in inorganic and organic materials (Graetsch et al., 1985), and $\mathrm{N}-\mathrm{H}$ bond stretches from organic materials (Kokot et al., 1994).

515 and $640 \mathrm{~cm}^{-1}$, characteristic of the mineral anatase (Beattie \& Gibson, 1968). This correlates with EDS analysis indicating the presence $\mathrm{TiO}_{2}$ mineral phases.

To summarize, the laser Raman microprobe has confirmed the presence of $\alpha$-quartz and clays (kaolinite) in the test agglutinate of the studied foraminifera. The laser Raman microprobe additionally confirms anatase as a $\mathrm{TiO}_{2}$ component recognized by EDS analysis of the test walls of $A$. balkwilli.

\section{Fourier transform infrared spectroscopy}

Results from the FTIR microprobe analysis are outlined in Fig. 4. Absorptions occur in specific regions of the acquired spectra due to the characteristic stretching and bending of particular molecular moieties. Quartz, clay (kaolinite) and anatase were identified as agglutinating material with EDS and laser Raman microprobe analysis and thus should be detectable with the FTIR microprobe, although the analytical window for FTIR analysis is slightly larger, lowering the spatial resolution of the microprobe technique.

Trochammina inflata, J. macrescens, $M$. fusca and $A$. balkwilli show similar FTIR spectra for agglutinated grains. Absorptions identified at 700 and $798 \mathrm{~cm}^{-1}$ correspond with $\mathrm{Si}-\mathrm{O}-\mathrm{Si}$ bond stretching vibrations for crystalline quartz $(700,785$ and $798 \mathrm{~cm}^{-1}$ ) (Farmer, 1974; Frölich, 1989). The strongest absorptions in all the spectra are in the region $995-1140 \mathrm{~cm}^{-1}$, varying slightly in bandwidth and position. In the analysis of quartz, this broad absorption is regarded as the envelope of several poorly resolved bands assignable to $\mathrm{Si}-\mathrm{O}$ bond stretches (Frölich, 1989). The variation in band frequencies can be influenced by variations of crystal alignment and orientation, and additionally by composition (Farmer, 1974). The 1796, 1883 and $1991 \mathrm{~cm}^{-1}$ absorptions in T. inflata, J. macrescens and $M$. fusca spectra,

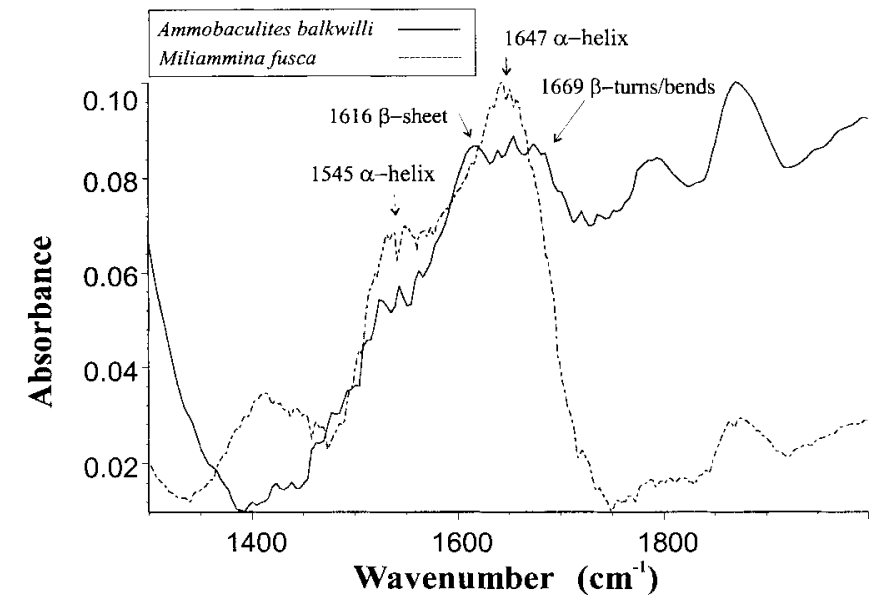

Fig. 5. Representative spectra from $A$. balkwilli, and $M$. fusca with absorptions in the spectral range $1400-2000 \mathrm{~cm}^{-1}$ relate to the occurrence of proteinaceous materials in the test. The main absorptions at 1647 and $1545 \mathrm{~cm}^{1}$ are representative of $\alpha$-helices; the $1669 \mathrm{~cm}^{-1}$ absorption is characteristic of $\beta$-turns and bends in the protein chain. A small absorption at $\approx 1617 \mathrm{~cm}^{-1}$ arises from vibration of the amino acid tyrosine in foraminiferal test materials.

and 1796,1875 and $1989 \mathrm{~cm}^{-1}$ in $A$. balkwilli spectra are additionally characteristic of overtone vibrational bands intrinsic to the $\alpha, \sigma$-, and $\Pi$ - spectra of quartz (Shimoda \& Aikawa, 1994).

Table 1. Reported FTIR spectral band absorbances from proteinaceous materials identifying secondary structures and also specific amino acids.

\begin{tabular}{|c|c|c|c|}
\hline Secondary structures & $\begin{array}{c}\text { Le Gal et al. } \\
\text { (1991) }\end{array}$ & $\begin{array}{l}\text { Scórko- } \\
\text { Glonek } \\
\text { et al. } 1995\end{array}$ & $\begin{array}{c}\text { Trouillier et al. } \\
\text { (1996) }\end{array}$ \\
\hline Turns + bends & 1694 & & \\
\hline Beta & & & 1691 \\
\hline Turns + bends & 1688 & & \\
\hline Turns + bends & 1683 & 1682 & 1682 \\
\hline Beta sheet parallel & $1675 \pm 4$ & 1673 & \\
\hline Turns and bends & $1670 \pm 2$ & & 1670 \\
\hline Turn, alpha & $1663 \pm 4$ & 1665 & 1660 \\
\hline Alpha helix & $1654 \pm 3$ & 1656 & 1653 \\
\hline Alpha, random coil & $1645 \pm 4$ & 1643 & \\
\hline Beta sheet antiparallel & $1637 \pm 3$ & 1639 & \\
\hline Beta sheet & $1631 \pm 3$ & 1635 & 1635 \\
\hline Beta sheet & $1624 \pm 4$ & 1628 & \\
\hline Beta sheet & & & 1625 \\
\hline Tyrosine & & 1612 & \\
\hline Amino acid side chain & & 1605 & \\
\hline Beta sheet & & & 1564 \\
\hline Alpha random & & & 1550 \\
\hline Alpha helix & & & 1545 \\
\hline Beta sheet & & & 1532 \\
\hline Tyrosine & & 1518 & \\
\hline
\end{tabular}

The influence of $\mathrm{Al}-\mathrm{O}, \mathrm{Si}-\mathrm{O}-\mathrm{Al}$ and $\mathrm{Ti}-\mathrm{O}$ bond vibrations arising from aluminosilicate phases (kaolinite) and titanium oxides (anatase) are also represented in the spectra. Absorption 
bands between 700 and $800 \mathrm{~cm}^{-1}$ are enhanced by the stretching vibration of $\mathrm{Al}-\mathrm{O}$ bonds (around 770 and $\approx 729-694 \mathrm{~cm}^{-1}$ ) (Handke \& Mozgawa, 1993) and Ti-O bond vibrations (800$650 \mathrm{~cm}^{-1}$ ) (Farmer, 1974) causing band frequency variation around those identified for quartz. Both $\mathrm{Si}-\mathrm{O}-\mathrm{Si}$ and $\mathrm{Si}-\mathrm{O}-\mathrm{Al}$ bridges are present in aluminosilicates and the presence of these bonds influences the region $950-1150 \mathrm{~cm}^{-1}$, producing absorption variation (frequency and intensity) in the foraminiferal spectra.

Fourier transform infrared analysis is ideal for the identification of organic materials, revealing additional information about the test composition (Allen et al., in press). FTIR analysis does not induce sample fluorescence, enabling highly organic materials to be analysed. Two broad absorptions are evident at 1545 and $1647 \mathrm{~cm}^{-1}$ in all the spectra. On closer investigation, smaller absorptions at 1617 and $1669 \mathrm{~cm}^{-1}$ can be detected in spectra from $A$. balkwilli and $M$. fusca. Proteinaceous substances in the test walls of the agglutinated foraminifera would cause absorptions to occur in these spectral regions. In all spectra, carbonyl ( $\mathrm{C}-\mathrm{O}$, stretch) and $\mathrm{N}-\mathrm{H}$ (bending) vibrations are identified at around $1650 \mathrm{~cm}^{-1}$ relating to the amide 1 unit, the main peptide link, of a protein (Kokot et al., 1994). Within the amide 1 region, small absorptions can identify features of the secondary structure of the protein i.e. $\alpha$-helices, $\beta$-sheets and turns. The intensities of such peaks may indicate the relative amounts of each type of secondary structure (Smith et al., 1994). Absorptions at 1617 and $1669 \mathrm{~cm}^{-1}$ may relate to the presence of tyrosine (a common amino acid) and beta turns/bends of the protein chain. The absorption at $1545 \mathrm{~cm}^{-1}$ in all the spectra arises from the $\mathrm{C}-\mathrm{N}$ stretch and the $\mathrm{N}-\mathrm{H}$ in-plane bending absorption in the amide 2 unit of the proteinaceous material (Kokot et al., 1994) (Fig. 5, Table 1). Organic aliphatic molecular moieties $\left(\mathrm{CH}_{2}\right.$ and $\left.\mathrm{CH}_{3}\right)$ produce spectral absorptions at 2936 and $2972 \mathrm{~cm}^{-1}$ visible in all the spectra from $J$. macrescens, $T$. inflata and $M$. fusca, and at 2858, 2875, 2926 and $2966 \mathrm{~cm}^{-1}$ in the spectra from A. balkwilli. The identification of organic molecular entities identifies organic cements and lining material in all the foraminifera. Bands characteristic of organic material also occur in the lower frequency region ( 800 $1300 \mathrm{~cm}^{-1}$ ) of the FTIR spectra, but the presence of inorganic material tends to mask these vibrations and hence prohibit further characterization.

All the spectra have a broad absorption from $3200-3700 \mathrm{~cm}^{11}$, centring at $3400 \mathrm{~cm}^{-1}$, due to the fundamental $\mathrm{OH}$-stretching vibrations of molecular water and $\mathrm{SiOH}$ (Graetsch et al., 1985). This region provides additional evidence that both proteins and carbohydrate components exist within foraminiferal lining materials. $\mathrm{N}-\mathrm{H}$ bond stretches within proteinaceous components (Kokot et al., 1994) and vibrations arising from $\mathrm{O}-\mathrm{H}$ bond stretches within carbohydrate units held within the structure will additionally form absorptions in this region.

To summarize, FTIR analysis in the investigation of test components confirms the presence of the major mineral polymorphs present in the agglutinate, but compared with the laser Raman microprobe technique, the spatial resolution was reduced due to the increase in the sampling window. FTIR analysis successfully reveals the nature of the organic cementation phase in all the tests, which the other techniques were not able to detect.

\section{X-Ray diffraction}

The major constituents of the sediment were found by XRD analysis to be predominantly quartz, together with kaolinite and a small amount of mica and calcite. Anatase was not detected in the bulk sediment analysis, but was detected as a minor component in the analysis of the heavy mineral fraction. The percentage of this mineral in bulk sediment analysis is presumably below the limit of detection and hence is less than $10 \%$ of the overall composition of the sediment. Clay fraction analysis of the sediment identified the main mineral type as kaolinite with additional mica. Anatase was not detected, suggesting that less than $10 \%$ is present in the clay fraction of the sediment.

\section{DISCUSSION}

Agglutinated foraminifera from marginal marine areas near Southampton agglutinate quartz and aluminosilicates such as kaolinite for the construction of their test walls. The use of anatase grains for agglutination by $A$. balkwilli is distinctive. The initial observation of dark grains in the $A$. balkwilli test was followed with EDS analysis identifying high levels of Ti; Raman analysis characterized the actual polymorph of $\mathrm{TiO}_{2}$ as anatase. None of the other foraminifera analysed select these grains for incorporation into their test, and hence it appears that $A$. balkwilli selects the anatase grains specifically. The operative forces of selection are poorly understood and, although most agglutinated foraminifera appear not to select, reports of grain selection have been published (Avnimelech, 1952; Hokfer, 1953; Sliter, 1968; Salami, 1976; Jørgensen, 1977; Höttinger, 1986; Bender, 1989). Certain agglutinated foraminifera have been documented to preferentially select quartz particles in high carbonate (chalk) environments where the sediment contains only negligible amounts of quartz (Jørgensen, 1977). The use of anatase in $A$. balkwilli suggests that particle differentiation is taking place.

\section{Size selectivity}

Size differentiation might be a factor influencing the process of test construction. A. balkwilli utilizes particles of clay to silt size $(4-50 \mu \mathrm{m})$ for test construction, whereas $T$. inflata and $J$. macrescens select grains of the clay-sized fraction $(1-4 \mu \mathrm{m})$ from the sediment. Anatase was not detected by bulk XRD sedimentary analysis and hence is presumably present in only very small quantities in the sediment $(<10 \%)$. However, on heavy mineral separation, anatase was detectable, but remained a minor mineral phase of the sediment compared with haematite and magnetite. Grains of anatase and quartz present in the test walls of $A$. balkwilli occur in the silt-sand, slightly coarser size fraction of the sediment, whereas $J$. macrescens and $T$. inflata do not include anatase in their agglutinated material. Anatase may simply not be available in smaller size categories, hence excluding the mineral from their test walls. Agglutinated foraminifera are reported to select agglutinated grains according to chamber size and can vary the grain distributions depending on the wall area (Avnimelech, 1952; Hofker, 1953; Slama, 1954; Hedley, 1964; Salami, 1976; Bowser \& Bernhard, 1995).

\section{Grain density}

Heron-Allen \& Earland (1920) noted that certain foraminifera 


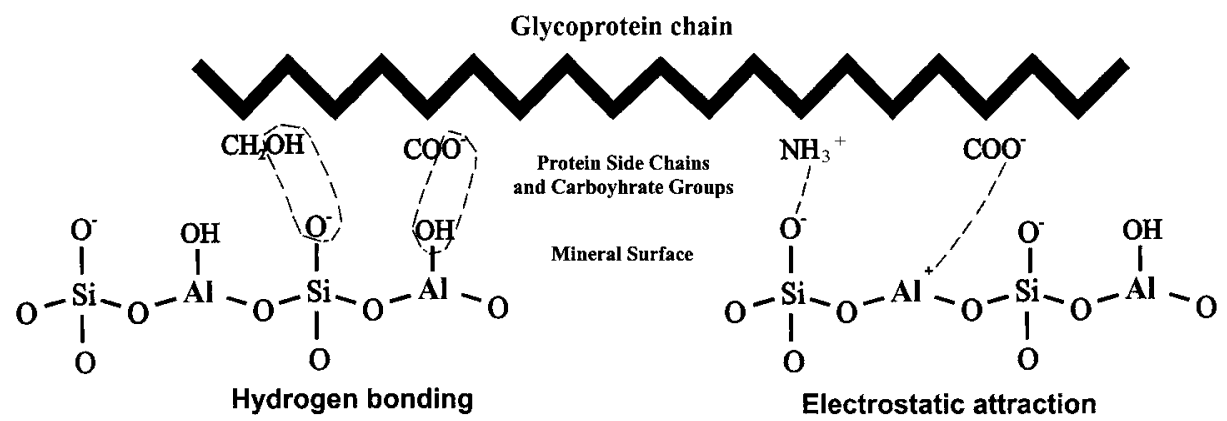

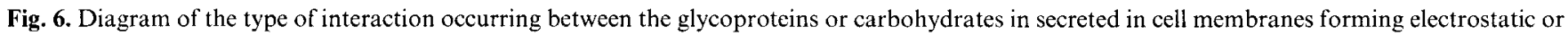
hydrogen bonds with the mineral surfaces.

select particles with higher specific gravities than sand grains. Experiments were later performed using minerals of varying specific gravity. The results indicated that no preference was made, leading to the conclusion that agglutinated foraminifera did not have the ability to detect variations in the specific gravity of minerals, although the reasoning behind the specific agglutination of dense minerals still remains unanswered (Salami, 1976). The specific gravity of anatase (3.9) is high compared with quartz and kaolinite (2.65 and 2.6, respectively); however, in an aqueous environment, the effect of a small percentage of heavy mineral in addition to other minerals in the test will make no significant difference to the overall specific gravity of the test, so there would be no advantage to infaunal foraminifera to agglutinate heavier particles.

Heron-Allen (1915) speculated that dense minerals would settle in the lower layers in a sediment profile after wave/current agitation. Depending on the movements of the foraminifera in the sediment, this could increase the probability of denser mineral agglutination. Perhaps $A$. balkwilli pervades these layers during movement through the sediment, enabling the agglutination of anatase along with quartz.

\section{Pseudopodial/secreted phase interaction}

Pseudopodia possess typical cell membranes (with a lipid bilayer, glycoprotein islands, surface glycoproteins and carbohydrate residues) which are the surfaces involved in sediment interactions (Fig. 6). The carbohydrate units act as feelers to attach, adhere to substrates (Warren, 1987) and also become involved in cell-cell, cell-matrix recognition processes (Alberts et al., 1989). Secretory adhesive products that arise from pseudopodia are also suggested to be involved in prey capture, locomotion, and test construction (Stuart, 1866; Schaudinn, 1893; Sandon, 1934; Jepps, 1942; Nyholm, 1956; Buchanan \& Hedley, 1960; Christiansen, 1971). The glycoprotein (glycosaminoglycan) secretions comprise the cement and lining materials present in foraminifera walls (Anderson \& Bé, 1976; Langer, 1992). Glycoprotein entities will also be capable of interacting with similar surfaces as they possess functional groups with a high surface charge (Bowser et al., 1984). Pseudopodia are capable of interacting with external interfaces, enabling the collection of and adhesion to specific materials. Polystyrene microspheres of various sizes, with net positive, negative or neutral surface charges, with varying degrees of hydrophobicity, were used in an experiment to see how the materials interacted with foraminiferal pseudopodia. The spheres were bound to, and moved along, pseudopodial surfaces, whereas bound bacteria were phagocytosed. This suggests that the pseudopodia are not specific in the surface selection of agglutinate; however, the foraminifera were able to differentiate between mineral and bacterial surfaces (Bowser \& Bloodgood, 1984; Bowser et al., 1984; Bowser \& Rieder, 1985, 1986). Experiments highlighting electrostatic interactive mechanisms between bacterial membranes and quartz interfaces have been reported previously (Beveridge \& Murray, 1980; Mera \& Beveridge, 1993). Surfaces of quartz, aluminosilcates and $\mathrm{TiO}_{2}$ materials have highly electrostatically charged regions which will attract sites with oppositely charged interfaces, such as organic foraminiferal materials, forming electrostatic and hydrogen bonds.

The results from the investigation indicate that the agglutinated foraminifera take advantage of materials available in the immediate surroundings, but that $A$. balkwilli is agglutinating materials that are not agglutinated by other foraminifera in the area. Additionally, $A$, balkwilli agglutinates silt-sized grains, whereas the other foraminifera agglutinate clay-sized particles, suggesting that a certain amount of selection may be taking place. Further investigations need to be carried out to determine which of the known mineral properties (size or chemotaxic properties) most influence selection.

\section{CONCLUSIONS}

This study investigated the nature of the tests of characteristic marginal marine agglutinated foraminifera. These forms definitely use particles of $\alpha$-quartz and kaolinite as major construction materials in their test formation. This is the first clear microprobe identification of the clay mineral type used in the tests of agglutinated foraminifera. The sediment in the surrounding area is composed of similar constituents to those in the test, so it reasonably follows that they include the most frequently available material in test construction. The more surprising feature is the occurrence of the mineral anatase as a constituent of the material agglutinated by $A$. balkwilli. This mineral is not common in the sediment and was below the detection limit of bulk XRD analysis $(<10 \%)$, but yet is detected as a minor phase on heavy mineral separation. Anatase is not detected in the clay-size fraction, suggesting that it is absent in this fraction or again exists in amounts below the levels 
of detection $(<10 \%)$. A. balkwilli appears to preferentially select silt-sized particles compared with the agglutination of clay-sized particles by the other foraminifera. This suggests that the organisms are able to differentiate between fractions of sediment. Additionally, silicate surfaces, aluminosilicate surfaces and $\mathrm{TiO}_{2}$ surfaces all have very similar properties and will readily react, through electrostatic attraction or hydrogen bonding, with oppositely charged surfaces, such as pseudopodial membranes and glycosaminoglycan secretory products.

Further research involving the investigation of foraminiferal pseudopodial interactions between different sedimentary size categories and various electrostatically charged surfaces should be performed to determine the controlling factors in the process of agglutination.

\section{ACKNOWLEDGEMENTS}

The authors thank Barbara Cressey for assistance within the Scanning Electron Microscopic Unit, and Barry Marsh for photographic processing. Ian Beattie's helpful discussion on spectroscopic issues is appreciated. K. A. was funded by a University of Southampton Scholarship.

Manuscript received 3 July 1998

Manuscript accepted 15 June 1999

\section{REFERENCES}

Alberts, B., Bray, D., Lewis, J., Raff, M., Roberts, K \& Watson, J. D. 1989. The Molecular Biology of the Cell, 2nd edn. Garland, New York, $1219 \mathrm{pp}$.

Allen, K., Roberts, S. \& Murray, J. W. in press. Analysis of organic components in the test wall of agglutinated foraminifera by Fourier transform infrared and pyrolysis gas chromatography/mass spectrometry. In: Hart, M \& Smart, C. (eds), Proceedings of the Fifth International Workshop on Agglutinated Foraminifera. Grzybowski Foundation Special Publication No. 4, in press.

Anderson, O. R.\& Bé, A. W. H. 1976. The ultrastructure of a planktonic foraminifera Globigerinoides sacculifer (Brady), and its symbiotic dinoflagellates. Journal of Foraminiferal Research, 6: $1-21$.

Avnimelech, M. 1952. Revision of the tubular monothalamia. Contributions Cushman Foundation Foraminiferal Research, 3: 60-68.

Beattie, I. R \& Gibson, T. R. 1968. Single crystal laser Raman spectroscopy. Proceedings of the Royal Society, A307: 407-429.

Bender, H. 1989. Chamber formation and biomineralization in Textularia candeiana d'Orbigny. In: Program and abstracts of III International Workshop on Agglutinated Foraminifera III, 5, Tubingen, 17-28, September 1989.

Bender, H. \& Hemleben, C. 1988. Constructional aspects in test formation of some agglutinated foraminifera. In: Gradstein, F. M. and Rögl, F. (eds), Second Workshop on Agglutinated Foraminifera. Abhandlungen der Geologischen Bundesanstalt, 41: 13-21.

Beveridge, T. J. \& Murray, R. G. E. 1980. Sites of metal deposition in the cell wall of Bacillus subtilis. Journal of Bacteriology, 141: 876-887.

Bowser, S. S. \& Bernhard, J. M. 1995. Structure, bioadhesive distribution and elastic properties of the test of Astrammina rara (Protozoa; Foraminiferida). Journal of Eukaryotic Microbiology, 40: 121-131.

Bowser, S. S. \& Bloodgood, R. A. 1984. Evidence against surf-riding as a general mechanism for surface motility. Cell Motility, 4: 305-314.

Bowser, S. S. \& Rieder, C. L. 1985 . Evidence that cell surface motility in Allogromia is mediated by cytoplasmic microtubules. Canadian Journal of Biochemistry and Cell Biology, 63: 608-620.

Bowser, S. S. \& Rieder, C. L. 1986. Microtubule-dependent reticulopodial surface motiliy: Reversible inhibition on plasma membrane blebs. Annals of the New York Academy of Sciences, 466: 933-935.

Bowser, S. S., Israel, H. A., McGee-Russell, S. M. \& Reider, C. L. 1984. Surface transport properties of reticulopodia: do intracellular and extracellular motility share a common mechanism? Cell Biology
International Reports, 8: 1051-1062.

Buchanan, J. B. \& Hedley, R. H. 1960. A contribution to the biology of Astrorhiza limicola (foraminifera). Journal of the Marine Biological Association of the United Kingdom, 39: 549-560.

Christiansen, O. 1971. Notes on the biology of foraminifera. Vie et Milieu, Suppl., 22: 465-477.

Deer, W. A., Howie, R. A. \& Zussman, J. 1966. An Introduction to the Rock-forming Minerals, 2nd edn. Longman Scientific and Technical, Harlow, 528 pp.

Farmer, V. C. 1974. The infrared spectra of minerals. Mineral Society Monograph, 4: $539 \mathrm{pp}$.

Frölich, F. 1989. Deep sea biogenic silica: new structural and analytical data from infrared analysis - geological implications. Terra Nova, 1: 267-273.

Frost, R. L. 1997. The structure of the kaolinite minerals - a FTRaman study. Clay Minerals, 32: 65-77.

Gooday, A. J., Nott, J. A., Davies, S. \& Mann, S. 1994. Apatite particles in the test wall of the large agglutinated foraminifera Bathysiphon. Journal of the Marine Biological Association UK, 75: 469-481.

Graetsch, H., Flörke, O. W. \& Miehe, G. 1985. The nature of water in chalcedony and opal-C from Brazilian agate geodes. Physical Chemistry of Minerals, 12: $300-306$.

Handke, M. \& Mozgawa, W. 1993. Vibrational spectroscopy of the amorphous silicates. Vibrational Spectroscopy, 5: 75-84.

Hedley, R. H. 1964. The biology of foraminifera. International Review of General and Experimental Zoology, 1: 1-45.

Heron-Allen, E. \& Earland, A. 1915. A short statement upon the theory, and the phenomena of purpose and intelligence exhibited by the protozoa, as illustrated by selection and behaviour in the foraminifera. Journal of Microscopy, 6: 547-557.

Heron-Allen, E. \& Earland, A. 1920. An experimental study of the foraminiferal species Verneuilina polystropha (Reuss); and some others, being a contribution to a discussion on the origin, evolution and transmission of biological characters. Proceedings of the Royal Irish Academy, B35: 153-177.

Hokfer, J. 1953. Arenaceous tests in foraminifera-chalk or silica? Micropaleontologist, 7: 65-66.

Hohenegger, J. 1990. On the way to the optimal supragenic classification of agglutinated foraminifera. In: Hemleben, C., Kaminski, M. A., Kuhnt, W. \& Scott, D. (eds) Paleoecology, Biostratigraphy, Paleoceanography and Taxonomy of Agglutinated Foraminifera. Kluwer Academic, Dordrecht, 25-35.

Höttinger, L. 1986. Construction and function of foraminiferal shells In: Leadbeater, B. S. C. and Riding, R. (eds) Biomineralization in Lower Plants and Animals. Clarendon Press, Oxford, 219-235.

Jepps, M. W. 1942. Studies on Polystomella Lamark/Foraminifera. Journal of the Marine Biological Association UK, 25: 607-666.

Johnston, C. T., Sposito, G. \& Birge, R. R. 1985. Raman spectroscopic study of kaolinite in aqueous suspension. Clays and Clay Minerals, 33; 483-489.

Jørgensen, N. O. 1977. Wall structure of some arenaceous foraminifera from the Maastrictian White Chalk (Denmark). Journal of Foraminiferal Research, 7: 313-321.

Kokot, S., Cheng, J. \& Gill, N. 1994. Comparative study of metal ion interactions with wool keratin using chemometrics. Analyst, 119: 677681

Langer, M. R. 1992. Biosynthesis of glycosaminoglycans in foraminifera: A review. Marine Micropaleontology, 19: 245-251.

Lefurgey, A. 1978. Scanning electron microscopic characterization of recent arenaceous foraminifera. Scanning Electron Microscopy, 2: 579585.

LeGal, J. M., Manfait, M. \& Theophanides, T. 1991. Applications of FTIR spectroscopy in structural studies of cells and bacteria. Journal of Molecular Structure, 242: 397-407.

Loh, E. 1973. Optical vibrations in sheet silicates. Journal of Physics C: Solid State Physics, 6: 1091-1104

Mera, M. U. \& Beveridge, T. J. 1993. Mechanisms of silicate binding to the bacterial cell wall in Bacillus subtilis. Journal of Bacteriology, 175: 1936-1945.

Nyholm, K. G. 1956. On the life cycle and cytology of the foraminifera Nemogullmia longevariabilis. Zoologiska Bidrag Fran Uppsala, 31: 483-495. 
Roberts, S. \& Murray, J. W. 1995. Characterization of cement mineralogy in agglutinated foraminifera (Protista) by Raman spectroscopy. Journal of the Geological Society, London, 152: 7-9.

Roberts, S., Tricker, P. M. \& Marshall, J. E. A. 1995. Raman spectroscopy of chitinozoans as a maturation indicator. Organic Geochemistry, 23: 223-228.

Salami, M. B. 1976. Biology of Trochammina cf. T. quadriloba Höglund (1947), an agglutinating foraminifer. Journal of Foraminiferal Research, 6: 142-153.

Sandon, H. 1934. Pseudopodial movements of foraminifera. Nature, 133: 761-762.

Schaudinn, F. 1893. Myxotheca arenilega nov.gen,, nov.spec. Ein neuer mariner Rhizopode. 2. Wissenschafftliche Zoologie, 57: 18-31.

Scórko-Glonek, J., Krzewski, K., Lipinska, B., Bertoli, E. \& Tanfani, F. 1995. Composition and structure of wild type Htr A heat stock protease and mutant Htr A proteins. Journal of Biological Chemistry, 270: 11 140-11 146 .

Shimoda, K. \& Aikawa, N. 1994. Absorption-coefficients of overtone and comination-modes of quartz. Mineralogical Magazine, 58: 601606.

Slama, D. C. 1954. Arenaceous tests in foraminifera - an experiment. Micropaleontologist, 8: 33-34.

Sliter, W. V. 1968. Shell material variation in the agglutinated foraminifer Trochammina pacifica Cushman. Tulane Studies Geology and Paleontology, 6: 80-84.

Smith, K. F., Haris, P. I., Chapman, D., Reid, K. B. M. \& Perkins, S. J.
1994. Beta-sheet secondary structure of trimeric globular domain of Clq of complement and collagen types VIII and X by FTIR spectroscopy and averaged structure predictions. Biochemical Journal, 301: $249-256$.

Stuart, A. 1866. Über Coscinosphaera ciliosa, eine neue Radiolaria. 2. Wissenschafftliche Zoologie, 57: 18-31.

Towe, K. M. 1977. The crystallography of Patellina corrugata Williamson: a-axis preferred orientation. Journal of Foraminiferal Research, 1: $58-61$.

Trouillier, A., Gerwent, K., \& Dupont, Y. 1996. A time-resolved Fourier transform infrared difference spectrocopic study of the sarcoplasmic reticulum $\mathrm{Ca}^{2+}$-ATPase: kinetics of the high affinity calcium binding at low temperature. Biophysical Journal, 71: 2970-2983.

Vénec-Peyré, M.-T. \& Jaeschk-Boyer, H. 1978. Application de la microsonde moléculaire à laser mole à l'étude du test de quelques foraminifères calcaires. Comptes Rendus de l'Academie des Sciences Paris, 287: 607-610.

Vénec-Peyré, M.-T. \& Jaeschk-Boyer, H. 1979. MicropaléontologieIntérêt de la microsonde moléculaire à laser mole en systematique; étude du foraminifère Rosalina posidonicola (Colom) Comptes Rendus de l'Academie des Sciences Paris, 288: 819-821.

Warren, R. C. 1987. Physics and the Architecture of Cell Membranes. Adam Holger, Bristol, $226 \mathrm{pp}$.

Weiner, S. \& Erez, J. 1985. Organic matrix of the shell of the foraminifera Heterostegina depressa. Journal of Foraminiferal Research, 14: 206-212. 